\title{
Механізм управління системою державних оборонних закупівель України
}

\section{Олена Голота ${ }^{A}$}

Received: June 6, 2020 | Revised: June 15, 2020 | Accepted: June 30, 2020

JEL Classification: Z3, M53, M54.

DOI: $10.33445 /$ sds.2020.10.3.11

\begin{abstract}
Анотація
Стаття присвячена вивченню теоретичних підходів до визначення понять "механізм управління" та "організаційно-економічний механізм управління" з метою визначення поняття "організаційно-економічного механізму управління системою державних оборонних закупівель". Проаналізовано погляди вчених на поняття "механізм управління", "організаційний механізм", "економічний механізм" та "організаційно-економічний механізм управління"; визначено, що категорія "механізм управління" $є$ складовою "організаційно-економічного механізму функціонування" будь-якої соціально-економічної системи та надано авторське бачення поняття "організаційно-економічного механізму управління системою державних оборонних закупівель". Визначено зовнішні та внутрішні фактори, що впливають на механізм управління системою державних оборонних закупівель. Сформульований поняттєвй апарат $\epsilon$ основою для подальшого вивчення шляхів підвищення ефективності вказаного управління.
\end{abstract}

Ключові слова: система державних оборонних закупівель; механізм управління; організаційно-економічний механізм управління; озброєння і військова техніка; оборонно-промисловий комплекс; сектор безпеки та оборони.

\section{Постановка проблеми}

В умовах "гібридної" агресії з боку Російської федерації та проведення в Україні операції об'єднаних сил (ООС) особливої актуальності набуває проблема підвищення ефективності державного управління, зокрема у сфері державних оборонних закупівель. Проблема ефективності роботи органів державної влади у сфері державних оборонних закупівель у багатьох випадках зводиться до низького рівня фінансування програм на закупівлю товарів, робіт та послуг оборонного призначення, а також неефективного його використання на зазначені цілі. Але за такого вирішення проблеми поза увагою науковців та практиків залишається найважливіше - удосконалення самого механізму управління системою державних оборонних закупівель.

Задля визначення можливих шляхів підвищення ефективності управління та розвитку системи державних оборонних закупівель доцільним $€$ вивчення організаційно-економічного механізму управління зазначеної системи, а також зовнішніх та внутрішніх факторів, що впливають на вказаний механізм.

\section{Аналіз останніх досліджень та публікацій}

$\begin{aligned} & \text { Дослідженню } \text { різних аспектів організаційно-економічного } \\ & \text { функціонування механізму управління та присвячено праці таких авторів, як }\end{aligned}$

А Національний університет оборони України імені Івана Черняховського, Україна, докторант, к.е.н., доцент, е-mail: golota_I@ukr.net, ORCID: 00000003-4323-4344 
Н. Брюховецька

В. Жданова,

О. Єрьоменко-Григоренко,

п. Єгоров,

О. Ковалюк,

А. Кульман,

С. Капталан

Ю. Лисенко,

Н. Удальцової,

О. Літвінов,

К. Холодкова.

Українськими вченими такими як В. Бадрак,

В. Бегма,

М. Білокур,

І. Борохвостов,

В. Горбулін,

$€$ К. Красников,

І. Чепков,

В. Шемаєв та ін. достатньо глибоко досліджуються питання систематизованих основ сутності воєнно-технічної політики держави, розвитку її оборонно-промислової складової, підходів до формування державного оборонного замовлення.

Водночас, у галузі наукових досліджень управління системою державних оборонних закупівель досліджувались окремі її напрямки. Разом із тим, на поточний час, наукові напрацювання 3 комплексного дослідження зазначеної проблеми, нажаль відсутні.

\section{Постановка завдання}

Метою даної статті $\epsilon$ аналіз поглядів вчених і практиків на сутність категорій "механізм управління" та “організаційноекономічний механізм" для виокремлення поняття "організаційно-економічний механізм управління системою державних оборонних закупівель", а також виділити зовнішні та внутрішні фактори, що впливають на ефективність управління зазначеною системою в Україні для подальшого дослідження шляхів підвищення ефективності вказаного управління.

\section{Виклад основного матеріалу}

Ефективне функціонування та розвиток системи держаних оборонних закупівель $\epsilon$ досить актуальною проблемою як з точки зору виконання завдання підвищення рівня спроможностей сил оборони країни, так і 3 позицій забезпечення раціонального витрачання бюджетних коштів.

Задля ефективного функціонування вказаної системи першочерговим завданням $\epsilon$ забезпечення ефективного управління системою держаних оборонних закупівель.

Так, на думку О. Таран-Лала на рівні організаційних процесів, що формують функціональну орієнтованість конструкції будьякої соціально-економічної системи, її поведінки і розвитку можна виокремити три основні чинники, від яких залежить можливість і ефективність організаційної дії: ресурсне й інформаційне забезпечення; управління, тобто вироблення керуючої інформації, доведення ії до виконавчих підсистем і контроль за виконанням; виконання, тобто перетворення керуючої інформації безпосередньо на функціональні ефекти [1].

В свою чергу, авторка розглядає управління, як взаємодію між системою-частиною (підсистемою) і вищестоящою системою (надсистемою), спрямовану на досягнення $\begin{array}{lll}\begin{array}{l}\text { функціональної } \\ \text { надсистеми [2]. } \\ \text { Погоджуючись }\end{array} & \text { зі } & \text { збереження } \\ \text { зазначеними }\end{array}$ твердженнями вважаємо за доцільне вивчити механізм управління системою державних оборонних закупівель.

В економічній науці поняття "механізм" використовується у переносному значенні, а саме як "внутрішня будова, як система функціонування та як апарат діяльності" [3].

В свою чергу, О. Ковалюк під механізмом управління розуміє форми, методи, важелі та інструменти, а також нормативно-правове, інформаційне та політичне забезпечення. Базовим елементом визначення $\epsilon$ понятя "механізм". Саме це поняття було запозичене представниками гуманітарних наук з механіки і загалом означає систему ланок, що перетворюють рух одних ланок на необхідний рух інших, до того ж існують вхідна і вихідна ланки [4]. Тут ідеться про модель системи (технічної) для виконання певної роботи. А. Кульман, використовує вказані базові знання, але вже по відношенні до макроекономіки, підкреслює, що “механізм" можна визначити як необхідний взаємозв' язок, що виникає між різними економічними явищами. Механізм містить певну послідовність економічних явищ: його 
елементами одночасно виступають вхідне і вихідне явища, а також весь процес, що відбувається в інтервалах між ними. А. Кульман зауважує, що механізм - це система взаємозв'язків економічних явищ, що виникають за певних умов під впливом початкового імпульсу [3, С. 13-14.]. “Механізм управління" в інтерпретації А. Кульмана - це природна система, яка виникла в ринковій економіці, але, в свою чергу варто зазначити, що вказане твердження $\epsilon$ не повною мірою вірним. На думку Н. Брюховецької, “механізм управління" - це штучна система, спеціально сконструйована для досягнення певних цілей у визначеній сфері людської діяльності [4]. Погоджуючись 3 думкою автора, слід зазначити, що залежно від переваги акцентів на тих чи інших методах управління, сам механізм управління буде отримувати відповідну назву, далі розглянемо де-які 3 механізмів управління, які використовуються в економіці.
В свою чергу, з огляду на внутрішню будову механізму управління варто звернути увагу, що К. Холодкова трактує механізм управління як сукупність конкретних методів, інструментів, нормативно-правового та інформаційно забезпечення, за допомогою яких реалізується вплив на об'єкти і процеси управління для досягнення поставлених цілей функціонування і розвитку [5].

Варто зазначити, що автором були розглянуті суб'єкти, об'єкти, цілі, принципи та функції системи державних оборонних закупівель на макроекономічному рівні та на мезо- і мікрорівнях на прикладі Міністерства оборони України у попередніх дослідженнях $[6 ; 7]$.

Крім того, необхідно відмітити, що в економіці використовується велика кількість механізмів управління, це і господарський, i економічний, і ринковий, і соціальний, i організаційний, і організаційно-економічний тощо.

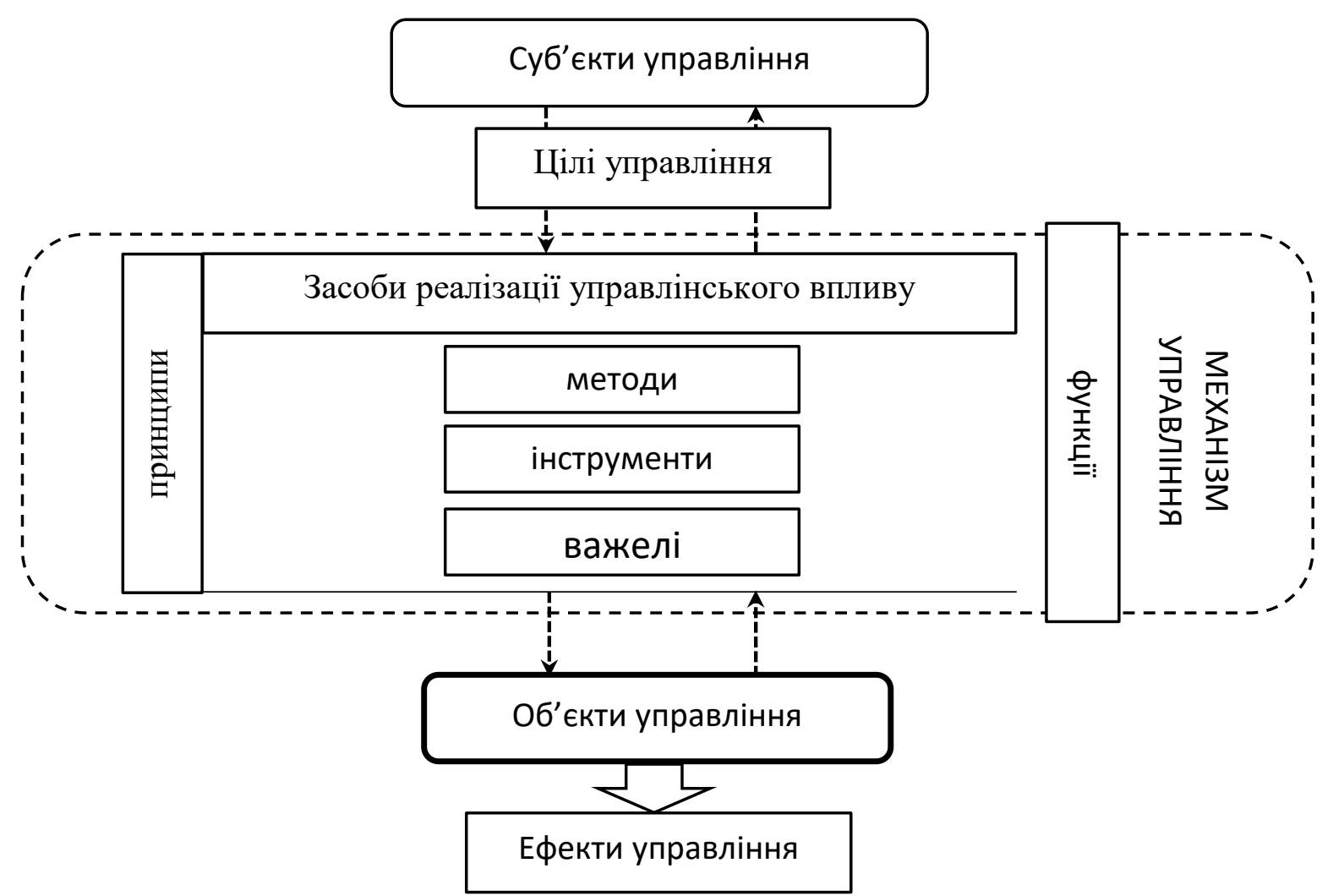

Мал. 1 - Механізм управління

Розроблено на основі [5] 
Враховуючи той факт, що більшість авторів зауважують на тому, що головним засобом досягнення цілей $є$ застосування організаційноекономічного механізму управління, оскільки окремо організаційні важелі впливу на об'єкт управління без врахування економічних законів і закономірностей не в змозі досягти необхідного результату, розглянемо погляди вчених на вказаний механізм.

На думку В.Жданова, економічний механізм включає необхідні взаємозв'язки, що виникають між різними економічними явищами i приводять до очікуваних результатів. Організаційний механізм включає систему методів, способів і прийомів формування й регулювання відносин об'єктів із внутрішнім і зовнішнім середовищем [8].

В свою чергу, О. Літвінов та С. Капталан під економічним механізмом розуміють сукупність, систему елементів впливу на економічні інтереси суб'єктів господарювання, яка враховує особливості його зовнішнього та внутрішнього середовища. В свою чергу під організаційним механізмом вказані вчені пропонують вважати сукупність управлінських дій, які спрямовані на організацію взаємодії між внутрішніми елементами в середині системи із врахуванням впливу зовнішнього середовища [9, С. 63-64].

Відповідно, організаційно-економічний механізм управління на думку вище згаданих О. Літвінова та С. Капталана - це сукупність управлінських дій спрямованих на організацію взаємодії між елементами системи з метою досягнення їх економічних інтересів із врахуванням особливостей зовнішнього та внутрішнього середовища [9, С. 64].

Лисенко Ю. та П. Єгоров щодо організаційно-економічного механізму зазначають: “...це система формування цілей і стимулів, які дозволяють перетворити у процесі трудової діяльності рух (динаміку) матеріальних і духовних потреб членів суспільства на рух засобів виробництва і його кінцевих результатів, спрямованих на задоволення платоспроможного попиту споживачів" [10].

Кендюков О. говорить, що Ю. Лисенко та П. Єгоров розглядають організаційно- економічний механізм як систему, та запропоноване визначення обмежується “системою формування цілей і стимулів". Варто зазначити, що процес управління не обмежується лише питанням формування цілей і стимулів: він допускає реалізацію й інших функцій управління - планування, організації та контролю. Окрім того, у запропонованому Ю. Лисенком і П. Єгоровим визначенні не дістали відображення такі найважливіші елементи механізму управління, як його методи, процедури і структура. Ю. Лисенко і П. Єгоров, відзначаючи, що “ядром організаційно-економічного механізму $\epsilon$ система стимулів, які формують спонукальні мотиви до підвищення ефективності функціонування виробничих систем", поділяють цю систему на дві підсистеми: командно-адміністративних і соціальноекономічних стимулів. Командноадміністративні стимули примушують до праці, а соціально-економічні - зацікавлюють працівників до високоефективної роботи [11]. Дещо інший підхід до визначення організаційно-економічного механізму управління демонструють О. ЄрьоменкоГригоренко [12] та Б. Іваненко [13]. За визначенням О. Єрьоменка-Григоренка, “організаційно-економічнй механізм управління підприємством являє собою систему технологічного, економічного, організаційного і соціального блоків, які включають до себе їх елементи".

3 інших позицій розглядає організаційноекономічний механізм управління І. БулєєВ - як сукупність форм, методів та інструментів управління [14]. Тут уже спостерігається управлінський підхід до процесу управління і засобів його реалізації. Однак зміст понятяя "механізм" і надалі залишається нечітким, оскільки самі по собі форми, методи та інструменти не забезпечують бажаного впливу на об'єкт управління.

В свою чергу, розглядаючи організаційноекономічний механізм державних закупівель послуг у своєму досліджені О.ОвсянюкБердадіна трактує його, як систему економічних, правових, адміністративних методів, форм, прийомів, інструментів і 
важелів впливу та відносин, що виникають із приводу закупівлі послуг за державні кошти [15].

На думку Н.Удальцової, з чим доцільно погодитись, “механізм управління" $\epsilon$ складовою частиною "організаційноекономічного механізму функціонування галузі" і являє собою ту його підсистему, яка пов'язана 3 керуючим впливом органів управління за допомогою реалізації методів та інструментів впливу на процеси виробництва на основі принципів узгодження інтересів між підприємствами галузі і державною політикою розвитку галузі [16]. Тобто, механізм управління є пусковим гачком функціонування механізму як такого та взаємодії держави та господарюючих суб'єктів, а також взаємодії органів управління підприємства та підрозділів підприємства на основі паритету відносин держави та господарюючих суб'єктів. На прикладі, системи державних оборонних закупівель держава виступає і як замовник товарів, робіт та послуг задля задоволення оборонних потреб, і як власник підприємств виконавців зазначеного замовлення.

Тому, на підставі проведеного аналізу стає можливим трактувати організаційноекономічний механізм управління системою державних оборонних закупівель як сукупність принципів і методів, функцій та мотивів, інструментів і обмежень, які забезпечують прийняття рішень щодо функціонування системи державних оборонних закупівель в мінливих умовах зовнішнього та внутрішнього середовища системи.

Варто зазначити, що організаційний механізм охоплює організацію структури керуючої системи (статики) та організацію процесу функціонування системи, якою управляють (динаміки) [17; 18; 19]. Тому, від структури управління значною мірою залежить дієвість механізму. Вона представлена наступними складовими елементами: правила, організаційно-правові нормативи і стандарти, які визначають і регулюють структуру управління, обов'язки, права і відповідальність органів управління, організацію процесу їх діяльності; розподіл робіт між різними виконавцями; оснащення управлінської праці засобами оргтехніки, чисельність працівників в управлінні, матеріальне і моральне стимулювання їхньої праці.

В свою чергу, необхідно зазначити, що організаційно-економічний механізм функціонування системи державних оборонних закупівель представляє собою сукупність (систему) певних форм і методів організації та реалізації військово-економічних відносин, що виникають між суб'єктами вказаної системи, і включає організаційну структуру та підсистеми нормативноправового, кадрового, фінансовоекономічного, інформаційного, аналітичного, методичного і технологічного забезпечення, зовнішнього і внутрішнього контролю та аудиту [19], зазначений механізм було розглянуто автором у попередньому дослідженні [7].

Слід зазначити, що де-які вчені розглядають механізм управління у вузькому розумінні як статичну систему, шо слугує інструментом організації управлінських явищ та процесів. В той же час, у широкому розумінні механізм управління розглядається як засіб реалізації владних відносин, реальне функціонування усієї статичної єдності елементів. [21].

Сучасний етап розвитку України характеризується суттєвими змінами практично всього комплексу як зовнішніх, так і внутрішніх факторів, що, у свою чергу, потребує корегування підходів до воєнного будівництва, до його фінансово-економічного забезпечення, та, відповідно, до системи управління цими процесами, або до воєнно-економічної політики (ВЕП) держави взагалі [22].

В свою чергу, формування механізму державного управління макроекономічним розвитком системи державних оборонних закупівель здійснюється під впливом специфіки оборонних потреб країни. За таких умов система управління оборонними закупівлями України характеризується:

переважанням закупівель у єдиного постачальника;

недосконалістю системи планування, регламентації відбору постачальників, системи контроля та підвищення кваліфікації кадрів у сфері оборонних закупівель; 
недостатністю ресурсного забезпечення системи оборонних закупівель та ефективності використання наявних ресурсів;

несвоєчасністю фінансування оборонного замовлення;

обмеженістю інформування постачальників щодо оборонних закупівель, які проводяться в режимі надмірної секретності;

відсутністю централізованих поставок однотипних товарів для усіх силових структур.

Причинами, що знижують ефективність системи оборонних закупівель, є:

недосконалість правової основи механізму планування, проведення та контролю оборонних закупівель;

наявність високого рівня корупційних ризиків;

недостатність інформації у замовника щодо кон'юнктури ринку закупівель;

нерозвиненість інститутів ринкової економіки та конкурентного середовища;

недостатній рівень аналітичного, методичного і технологічного забезпечення системи державних оборонних закупівель;

не координованість діяльності з організації закупівель силовими відомствами.

Підвищення ефективності використання бюджетних коштів забезпечується формуванням цілісної системи управління державними закупівлями, включає: військовополітичний механізм; організаційно-правовий механізм; бюджетно-фінансовий механізм; інформаційний механізм тощо.

Організаційна структура системи державних закупівель для потреб оборони і безпеки представлена сукупністю функціонуючих органів різних рівнів, яка за рівнем прийняття рішень має трирівневу будову: макро(загальнодержавний), мезо- (рівень окремого державного замовника, тобто відомчий) i мікрорівень (рівень окремого суб'єкта управління).

Формування ефективного організаційноекономічного механізму управління системою державних оборонних закупівель, поряд 3 труднощами економічного характеру, ускладняються також специфічними особливостями оборонної сфери (таємність, тривалий цикл розробки і впровадження озброєння та військової техніки (ОВТ), значні витрати на дослідження та ін.), відставанням процесів інституціоналізації від інших напрямків розвитку ринку оборонних закупівель.

Слід врахувати, що вхідними даними системи державних оборонних закупівель для визначення підходів управління зазначеною системою передусім $\epsilon$ наявні потреби в оборонній продукції, а також фінансові i матеріальні ресурси для задоволення зазначених потреб. Відповідно вихідними даними системи є рівень задоволення потреб в оборонній продукції (товарах, роботах та послугах), які, відповідно, будуть відбиватись на рівні забезпечення національної безпеки і оборони.

Система державних оборонних закупівель, як і будь-яка інша соціально-економічна система, функціонує в умовах безперервно мінливого зовнішнього середовища, що $\epsilon, \mathrm{B}$ свою чергу, постійним джерелом можливостей і загроз для розвитку вказаної системи. У зазначених умовах правила, методи і технології, які позитивно зарекомендували себе в минулому та які є відносно стабільними перестають бути адекватними до поточних умов розвитку, що обумовлює необхідність пошуку нових підходів до організаційного розвитку системи.

Перед системою державних оборонних закупівель постає проблема розробки та практичного використання механізмів управління в залежності від цілей системи та впливу факторів внутрішнього і зовнішнього середовища.

Варто зазначити, що організаційноекономічний механізм управління системою державних оборонних закупівель, відповідно до її організаційної будови, можна розглядати як на макро- так і мезо-, мікрорівні. На макрорівні організаційно-економічний механізм управління системою - це форма організації взаємодії учасників ринку постачання оборонних товарів, послуг та робіт, замовників та координуючих органів, а також економічні методи і механізми забезпечення цієї взаємодії. На мезо- та мікрорівні - це система організаційно-економічних заходів, 
що стосуються підвищення ефективності закупівельних процесів на рівні окремого замовника, що означає наявність взаємопов'язаних організаційноадміністративних і економічних заходів. Вибір організаційно-економічного механізму, його концепція залежать від обраних цілей розвитку, напрямків стратегічного розвитку.

При формуванні організаційноекономічного механізму, а також його основних елементів необхідно вирішити такі завдання:

визначити цілі, завдання та принципи механізму управління;

визначити умови і чинники функціонування механізму управління;

визначити суб'єкти механізму управління;

сформувати об'єкти управління;

розробити методи, способи і інструменти управління;

визначити результат і розробити систему моніторингу результатів.

На підставі цілей системи та обраного напрямку стратегічного розвитку формуються параметри ефекту управління: результат, який повинен бути, досягнутий.

Задля того щоб можливо було сформувати підходи до підвищення ефективності функціонування організаційно-економічного механізму управління системою держаних оборонних закупівель спробуємо встановити фактори зовнішнього та внутрішнього впливу на вказану систему на макрорівні. Так, фактори зовнішнього впливу складаються 3 двох груп впливу:

перша група факторів впливає на конкретизацію вибору предмету закупівель та їх об'єми:

зміни в безпековому середовищі (геополітиці), а саме це: глобальні, регіональні та національні аспекти та воєнно-політична обстановка в регіоні довкола України; до того ж слід зазначити, що перерозподіл сил та загроз - "боротьба за вплив на світові фінансові та енергетичні потоки посилює глобальну воєннополітичну нестабільність, а як результат провідні держави збільшують розміри воєнних витрат, активізують розробку нових зразків озброєння, підвищують інтенсивність військових навчань"; також характер і масштаб воєнних загроз зумовлюють характер та об'єми розробок та закупівель оборонної продукції;

цілі, пріоритети та завдання воєнної політики держави, а саме: зміни у воєнній політиці держави, тобто засади внутрішньої та зовнішньої політики; базуючись на законі України "Про національну безпеку України" та воєнній доктрині, яку позицію займає держава, які спроможності планує розвивати; а також підходи до оптимальних розмірів фінансових (бюджетних) ресурсів (\% від ВВП), які виділяються на утримання сектору безпеки та оборони (в тому числі МОУ), а відповідно і на проведення оборонних закупівель, пріоритети у обсягах виділяємих ресурсів на розвиток ОВТ тощо;

рівень політичної корупції, що безпосередньо впливає на законодавче унормування та неформальний вплив на взаємодію суб'єктів системи державних оборонних закупівель, а також відповідно формування бюрократичної та низової корупції;

зміни науково-технічного прогресу (технологічні та інноваційні зміни), що обумовлює створення нових видів зброї, техніки, спорядження тощо та відповідно їх закупівлю;

економічна ситуація, а саме це: стійкість національної економіки до негативних зовнішніх впливів та розміри ВВП, які пливають на обсяг коштів, що виділяються на оборону, а відповідно і на здійснення оборонних закупівель; економічні регулятори, які впливають на функціонування підприємств оборонно-промислового комплексу (ОПК) (чи стимулюють вони розвиток конкуренції серед постачальників) та економічні механізми адресної державної підтримки та державного протекціонізму щодо прямої закупівлі у підприємств ОПК країни;

екологічна ситуація в країні та у регіоні, яка відповідно теж буде впливати на характер оборонних закупівель та їх об'єми;

друга група факторів впливає на характер підходів до закупівельних процедур: 
зміни в політичному курсі держави, а саме це: прихильність до певних тенденцій, трендів; рівень політичної корупції;

інноваційні зміни, а саме це: поява нових технологічних можливостей, які можуть підвищити ефективність закупівельного процесу та взаємодії суб'єктів системи; поява нових підходів, які можливо застосувати для взаємодії суб'єктів та для оптимізації процесу закупівель, що відповідно впливає на підходи щодо аналітичного, методичного та технічного забезпечення системи державних оборонних закупівель;

В свою чергу внутрішні фактори впливу це:

стан впровадження системних реформ у сфері національної безпеки і оборони, рівень ресурсного забезпечення сил оборони та стан використання наявних ресурсів;

рівень ефективності системи державного управління суб'єктами забезпечення національної безпеки та оборони України та механізмів планування розвитку таких суб'єктів;

рівень готовності замовників до відповіді на сучасні гібридні виклики та загрози; стан налагодження механізмів планування, формування та контролю за видатками на потреби оборони, а саме це: стан оборонного планування, контролю за використанням бюджетних коштів, формування цін на оборонну продукцію, роботи та послуги, а також приймання продукції, робіт та послуг;

рівень бюрократичної та низової корупції.

Розвиток системи державних оборонних закупівель забезпечуватиме чіткий розподіл відповідальності органів державного управління щодо функцій планування та проведення закупівель, укладання та виконання контрактів в рамках визначених повноважень, а також упровадження сучасних методів, що використовуються провідними країнами світу для посилення власних оборонних спроможностей, зокрема застосування принципу “всебічного підходу до оборони", методів планування на основі спроможностей, здійснення цілеспрямованої підготовки до виконання завдань за призначенням, логістичного забезпечення потреб оборони держави.

\section{Висновки}

У статті проаналізовано теоретичні погляди на поняття “механізм управління", “організаційний механізм", “економічний механізм", "організаційно-економічний механізм управління" та визначено, що категорія "механізм управління" $\epsilon$ складовою "організаційно-економічного функціонування" будь-якої соціальноекономічної системи.

На підставі проведеного аналізу надано авторське визначення категорії "організаційно-економічного механізму управління системою державних оборонних закупівель" як сукупності принципів і методів, функцій та мотивів, інструментів і обмежень, які забезпечують прийняття рішень щодо функціонування системи державних оборонних закупівель в мінливих умовах зовнішнього та внутрішнього середовища системи.
Встановлено фактори зовнішнього та внутрішнього впливу на системою державних оборонних закупівель. А саме, зовнішні фактори це: зміни в безпековому середовищі (геополітиці); цілі, пріоритети та завдання воєнної політики держави, зміни в політичному курсі держави; рівень політичної корупції; зміни науково-технічного прогресу; економічна ситуація в державі; економічні регулятори, які впливають на функціонування підприємств ОПК; екологічна ситуація в країні та у регіоні. В свою чергу внутрішні фактори впливу це: стан впровадження системних реформ, рівень ресурсного забезпечення; рівень ефективності системи державного управління у секторі національної безпеки та оборони; рівень готовності замовників; стан налагодження механізмів планування, формування та контролю; рівень бюрократичної та низової корупції у системі державних оборонних закупівель. 


\section{Список використаних джерел}

1. Таран-Лала О. M. Функціонування соціально-економічних систем: теорія та практика : монографія. Полтава : ПУЕТ, 2016. 332 c., с. 19

2. Кульман А. Экономические механизмы. М.: Прогресс Универс, 1993. 188 с.

3. Словарь русского языка: в 4-х томах (Малый академический словарь, МАС). М.: Рус. яз.; Полиграфресурсы, 1983. Т. 2. 700 с.

4. Брюховецька Н. Ю. Економічний механізм підприємства в ринковій економіці: методологія і практика. Донецьк: IEП НАН України, 1999. 276 с.

5. Холодкова К.С. Анализ подходов к определению сущности организационноэкономического механизма управления. Современные научные исследования и инновации. 2016. № $5 . \quad$ URL: http://web.snauka.ru/issues/2016/05/66404 (дата звернення 22.04.2020)

6. Голота О. П. Система оборонних закупівель України: теоретичний аспект. Ефрективна економіка. 2020. № $4 . \quad$ URL: http://www.economy.nayka.com.ua/?op=1 $\& z=7788$ (дата звернення: 26.06.2020). DOI: 10.32702/2307-2105-2020.4.72

7. Голота О. П. Організаційно-економічний механізм функціонування системи державних оборонних закупівель України. Ефективна економіка. 2020. № 6. URL: http://www.economy.nayka.com.ua/?op=1 $\& z=7986$ (дата звернення: 30.06.2020). DOI: 10.32702/2307-2105-2020.6.73

8. Егоров Д., К Кутилина О., Реймер Л. Сравнительный экономический анализ региональной экономики. Проблемы теории и практики. - М.: Эдиториал УРСС, 2008. -128 c.

9. Літвінов О. С., Капталан С. М. Визначення сутності та складових організаційноекономічного механізму управління підприємством в умовах інноваційного розвитку. Управління розвитком. 2016. № 3 (185). C. 59-65.
10. Лисенко Ю., Єгоров П. Організаційноекономічний механізм управління підприємством. Економіка України. 1997. № 1. С. 86-97.

11. Економічна енциклопедія: у 3 т. / відпов. ред. С. В. Мочерний. К. : Видавничий центр "Академія", 2001. Т. 2. 848 с.

12. Еременко-Григоренко О.А. Организационно-экономический механизм управления хозяйственной деятельностью предприятия: дис. ... канд. экон. наук: 08.06.01. / НАН Украины, Ин-т экономики пром-сти, 1999. 266 с.

13. Іваненко Б. М.

Формування організаційно-економічного механізму функціонування виробничого об'єднання в ринкових умовах: автореф. дис. ... канд. екон. наук: 08.06.01. / НАН України, Інститут економіки промисловості, 1997. $29 \mathrm{c}$.

14. Булеев И.П. Формирование организационно-экономического механизма управления предприятием по обработке цветных металлов. Донецк: ИЕП НАН Украины, 1993. 225 с.

15. Овсянюк-Бердадіна О. Ф. Організаційноекономічний механізм державних закупівель послуг: дис.... канд. екон. наук: 08.00.03 / Тернопільський національний економічний університет. Тернопіль, 2009. $249 \mathrm{c}$.

16. Удальцова Н. Л. Организационноэкономический механизм функционирования отрасли национальной экономики. Экономика и управление. 2012. 6 (91). С. 94-98.

17. Барсуков Д. П., $\quad$ Афанасьева О. В. Использование методов прогнозирования для решения задач информационностатистического анализа деятельности предприятий в условиях риска. Петербургский экономический журнал. 2013. № 1(1). С.73-78.

18. Осовская Г. В., Осовский О. А. Основы менеджмента: Учебное пособие. К.: "Кондор", 2006. 664 с. 
19. Магомедов М. Н. Оптимизация организационной структуры управления на примере газодобывающего предприятия. Известия СанктПетербургского государственного электротехнического университета ЛЭТИ. 2010. №8. С. 96-100.

20. Голота О. П. Нормативно-правове забезпечення як підсистема організаційно-економічного механізму функціонування системи державних оборонних закупівель. Ефрективна економіка. $2020 . \quad$ № $5 . \quad$ URL: http://www.economy.nayka.com.ua/?op=1 $\& z=7882$ (дата звернення: 29.05.2020). DOI: 10.32702/2307-2105-2020.5.67

21. Державне управління в Україні: навч. посіб. / за заг. ред. д-ра юрид. наук, проф. В. Б. Авер'янова. Київ, 1999. 350 с.

22. ЧепковІ.Б. та ін. Теорія озброєння. Науково-технічні проблеми та завдання: [монографія]: у 6-и т. Т. 6: Воєнноекономічний аналіз життєвого циклу озброєння та військової техніки: теоретико-методологічні засади. Київ : ВД Дмитра Бураго, 2018. 475 с.

\title{
Механізм управления системой государственных оборонных закупок Украины
}

\author{
Елена Голота ${ }^{\mathrm{A}}$
}

\author{
А Национальный университет обороны Украины, Украина, докторант, к.е.н. доцент, e-mail: golota_l@ukr.net
}

\begin{abstract}
Аннотация
Статья посвящена изучению теоретических подходов к определению понятий "механизм управления" и “организационно-экономический механизм управления" с целью определения понятия “организационно-экономического механизма управления системой государственных оборонных закупок". Проанализированы взгляды ученых на понятия "механизм управления", “организационный механизм", “экономический механизм" и "организационно-экономический механизм управления"; определено, что категория "механизм управления" является составляющей "организационноэкономического механизма функционирования" любой социально-экономической системы, а также предоставлено авторское видение понятия “организационноэкономический механизм управления системой государственных оборонных закупок". Определены внешние и внутренние факторы, влияющие на механизм управления системой государственных оборонных закупок. Сформулированный понятийный аппарат является основой для дальнейшего изучения путей повышения эффективности указанного управления.
\end{abstract}

Ключевые слова: система государственных оборонных закупок; механизм управления; организационно-экономический механизм управления; вооружение и военная техника; оборонно-промышленный комплекс; сектор безопасности и обороны.

\section{Management mechanism of the defence procurement (acquisition) system of Ukraine}

\author{
Olena Holota ${ }^{A}$ \\ AThe National Defence University of Ukraine named after Ivan Cherniakhovskyi, Doctoral candidate, \\ PhD, Associate Professor, e-mail: golota_l@ukr.net
}

\begin{abstract}
In the context of counteracting "hybrid" aggression by the Russian Federation, an essential indicator of the state of the national economy, national security and defence is the level of
\end{abstract}


efficiency of the acquisition (procurement) system as a means of state regulation. At the same time, the acquisition (procurement) system is also a means of managing the development of armaments and military equipment, which is extremely important to ensure the proper level of defence capabilities of Ukraine.

The article is devoted to the study of theoretical approaches to the definition of "management mechanism" and "organisational and economic management mechanism" to define the concept of "organisational and economic management mechanism of the defence acquisition (procurement) system" and to identify external and internal factors affecting the management of this system in Ukraine for further research on ways to improve the efficiency of this management.

The methodological basis of the article is the complex of methods, including methods of scientific cognition, analysis and synthesis, systematisation and scientific abstraction. The informational basis of the conducted research is the scientific works of the domestic and foreign scientists in the sphere of management, state (public) procurement and defence acquisitions (procurement) and awards.

As a result, based on the conducted analysis, the author determines that the category "management mechanism" is a component of the "organisational and economic mechanism of functioning" of any socio-economic system and provides the author's vision of the concept of "organisational and economic management mechanism of public defence procurement" as a set of principles and methods, functions and motives, tools and constraints that ensure decision-making on the functioning of public defence procurement in changing external and internal environment. Furthermore, author identifies external and internal factors influencing the management mechanism of the defence acquisition (procurement) system. The formulated conceptual apparatus is the basis for further study of ways to improve the efficiency of this management.

The results of this analysis formed the basis for further study of ways to improve the efficiency of the defence acquisition (procurement) system management of Ukraine.

Keywords: defence acquisition (procurement) system; management mechanism; organisational and economic mechanism of management; weapon, military equipment; defence industry; defence and security sector.

\section{References}

1. Taran-Lala, O. M. (2016), Funkcionuvannja socialjno-ekonomichnykh system: teorija ta praktyka : monoghrafija [Functioning of socio-economic systems: theory and practice: monograph], PUET, Poltava, Ukraine.

2. Kul'man, A. (1993), Jekonomicheskie mehanizmy [Economic mechanisms], Progress Univers, Moskov, Russian Federation.

3. Dictionary of the Russian language (1983) (Vols. 1-4, Vol. 2.) Moskov: Publishing Center "Poligrafresursy". SSSR [in Russian].

4. Briukhovetska, N. Yu. (1999), Ekonomichnyi mekhanizm pidpryiemstva $v$ rynkovii ekonomitsi: metodolohiia i praktyka [The economic mechanism of the enterprise in a market economy: methodology and practice], IEP NAN Ukrainy, Donetsk, Ukraine.
5. Holodkova, K. S. (2016), "Analysis of approaches to determining the essence of the organizational and economic management mechanism", Sovremennye nauchnye issledovanija i innovacii, [Online], vol. 5, available at: http://web.snauka.ru/issues/2016/05/66404 (Accessed 22 April 2020)

6. Holota, O. (2020), "Defence procurement (acquisition) system of Ukraine: theoretical aspect", Efektyvna ekonomika, [Online], vol. 4, available at: http://www.economy.nayka.com.ua/?op=1 $\& z=7788$ (Accessed 26 Jun 2020). DOI: 10.32702/2307-2105-2020.4.72

7. Holota, O. (2020), “Organisational and economic mechanism of functioning of the defence procurement (acquisition) system of Ukraine", Efektyvna ekonomika, [Online], vol. 
6, available at:

http://www.economy.nayka.com.ua/?op=1

$\& z=7986$ (Accessed 30 Jun 2020). DOI: 10.32702/2307-2105-2020.6.73

8. Egorov, D. Kutilina, O. Rejmer, L. (2008), Sravnitel'nyj jekonomicheskij analiz regional'noj jekonomiki. Problemy teorii i praktiki. [Comparative economic analysis of the regional economy. Problems of theory and practice], Editorial URSS, Moskov, Russian Federation.

9. Litvinov, O. S., Kaptalan, S. M. (2016), "Defining the essence and components of the organizational and economic mechanism of enterprise management in terms of innovative development", Upravlinnia rozvytkom, vol. 3(185), 59-65.

10. Lysenko, Yu. Yehorov, P. (1997), "Organizational and economic mechanism of enterprise management", Ekonomika Ukrainy, vol. 1, 86-97.

11. Mochernyj, S. V. (2001) Economic Encyclopedia (Vols. 1-3, Vol. 2.) Kyiv: Publishing Center "Academy" [in Ukrainian].

12. Eremenko-Grigorenko, O. A. (1999).

Organizational and economic mechanism for managing the economic activity of the enterprise (Ph.D. Thesis). Economics, organization and management of enterprises. Donetsk: NAS of Ukraine, Institute of Industrial Economics.

13. Ivanenko, B. M. (1997). Formation of organizational and economic mechanism of functioning of the production association in market conditions (Abstract of Ph.D. Thesis). Economics, organization and management of enterprises. Donetsk: NAS of Ukraine, Institute of Industrial Economics.

14. Buleev, I. P. (1993), Formirovanie organizacionno-jekonomicheskogo mehanizma upravlenija predprijatiem po obrabotke cvetnyh metallov [Formation of the organizational and economic mechanism for managing a non-ferrous metal processing enterprise], IEP NAN Ukrainy, Donetsk, Ukraine.
15. Ovsianiuk-Berdadina, O. F.

(2009). Organizational and economic mechanism of public procurement of services (Ph.D. Thesis). Economics and management of national economy. Ternopil: Ternopil National Economic University.

16. Udal'cova, N. L. (2012), “Organizational and economic mechanism of the functioning of the national economy", Jekonomika $i$ upravlenie, vol. 6(91), 94-98.

17. Barsukov, D. P. Afanas'eva, O. V. (2013), "Using forecasting methods to solve the problems of information-statistical analysis of enterprises in risk", Izvestija Peterburgskij jekonomicheskij zhurnal, vol. 1(1), 73-78.

18. Osovskaja, G. V. Osovskij, O. A. (2006), Osnovy menedzhmenta: Uchebnoe posobie [Management Basics: Study Guide], "Kondor", Kiev, Ukraine.

19. Magomedov, M. N. (2010), "Optimization of the organizational structure of management on the example of a gas producer", Izvestija Sankt-Peterburgskogo gosudarstvennogo jelektrotehnicheskogo universiteta LJeTI, vol. 8, 96-100.

20. Holota, O. (2020), "Regulatory and legal framework as a subsystem of the organisational and economic mechanism of functioning of the defence procurement (acquisition) system", Efektyvna ekonomika, [Online], vol. 5, available at: http://www.economy.nayka.com.ua/?op=1 $\& z=7882 \quad$ (Accessed 28 May 2020). DOI: 10.32702/2307-2105-2020.5.67

21. Averianov, V. B. (1999), Derzhavne upravlinnia v Ukraini: navch. posib. [Public administration in Ukraine: a textbook], Kiev, Ukraine.

22. Chepkov, I. B. \& others (2028) Teoriia ozbroiennia. Naukovo-tekhnichni problemy ta zavdannia : monoghrafija [Weapon theory. Scientific and technical problems and tasks: monograph] (Vols. 1-6, Vol. 6.), VD Dmytra Buraho, Kyiv, Ukraine. 